\title{
Impact of the bird-manure caused eutrophication on the abundance and diversity of chironomid larvae (Diptera; Chironomidae) in lakes of the Bolshoy Aynov Island (Russia, Barents Sea)
}

\author{
Viktor Baranov $^{1}$ and Ivan Nekhaev ${ }^{2}$ \\ ${ }^{1}$ Senckenberg Research Institute, Clamecystraße 12, 63571 Gelnhausen, Germany. \\ ${ }^{2}$ Laboratory of Macroecology and Biogeography of Invertebrates, Saint-Petersburg State University, \\ Universitatskaya Emb.7-9, Saint-Petersburg, 199034, Russia.
}

\begin{abstract}
We report on the perceived impact of bird faeces as an agent of organic matter transfer on the density and species richness of the Chironomidae in the lakes of the Bolshoy Aynov island (Barents Sea, Northern Russia). In total we recorded 15 species of Chironomidae. Highest species richness and specimen numbers were recorded in Lake Severnoe, closest to the large bird colony.
\end{abstract}

\section{Introduction}

Sea bird manure is an important source of nutrient transfer from aquatic ecosystems to terrestrial (Ellis et al. 2006). It is well known that removal of phosphorus and nitrogen from marine environments to terrestrial contributes to soil formation on the isles. Influx of nutrients with bird manure is crucial to maintain productivity of the northern aquatic systems, which are normally oligotrophic or dystrophic. Bird manure is also important for the formation of ornithogenic soils and waters (Tatur 2002). In some areas, like the maritime Antarctic, high Arctic and northern Europe, such ornithogenic landscapes are common and important for the functioning of the coastal and inland freshwater ecosystems (Tatur 2002). In this short communication, we will examine the Chironomidae communities in several small lakes of the Bolshoi Ainu Island in the secluded Ainu archipelago in the Barents Sea, close to Murmansk, Russia. This island is an important sea bird sanctuary, inhabited by large colonies of puffins, cormorants and little gulls (Khleboslov et al. 2005); thus, we hypothesized that this site would be a suitable place to study possible bird colonies impact on freshwater Chironomidae species richness and density.

\section{Materials and Methods}

Bolshoy Aynov Island is in the eastern part of Varangerfjord, Barents Sea (Russia). The island is about two kilometers long and about one and a half kilometers wide. The landscape is mainly flat (Fig 1). The vegetation is typical for the southern tundra. The climate of the Island is warmer than the climate of the adjacent coast of the Kola Peninsula because it is heated by the North Atlantic Current. The Bolshoy Aynov Island is protected and included in the Kandalaksha State Nature Reserve. The island has five small lakes (about 5-20 meters length) and one relatively large lake (more than 100 meters in length).

The material was collected on seven sites from four small lakes of Bolshoy Aynov Island. All the samples were collected by using a hand-net with mesh size $1000 \mu \mathrm{m}$ during mollusc collection, thus, due to the inappropriate mesh-size, smaller specimens probably were lost. Samples were preserved in formaldehyde. The samples were sorted by hand using an MBS-10 dissecting microscope with x56 magnification. The site descriptions are given in table 1.

Table 1. Characteristic of the collection sites.

\begin{tabular}{lll}
\hline Lake name & Substratum & Depth, cm \\
\hline Maloe (Site 1) & Silt with dead vegetation & $40-50$ \\
Maloe (Site 2) & Dead organic matter, living Fontinalis sp. and algae & 50 \\
Maloe (Site 3) & Fontinalis sp. & $60-70$ \\
Srednee & Dead organic matter & 70 \\
Severnoe (Site 1) & Silt, dead organic matter & 15 \\
Severnoe (Site 2) & Silt, dead organic matter & 120 \\
Zapadnoe (Site 1) & Silt, dead organic matter, sand & 40 \\
\hline
\end{tabular}




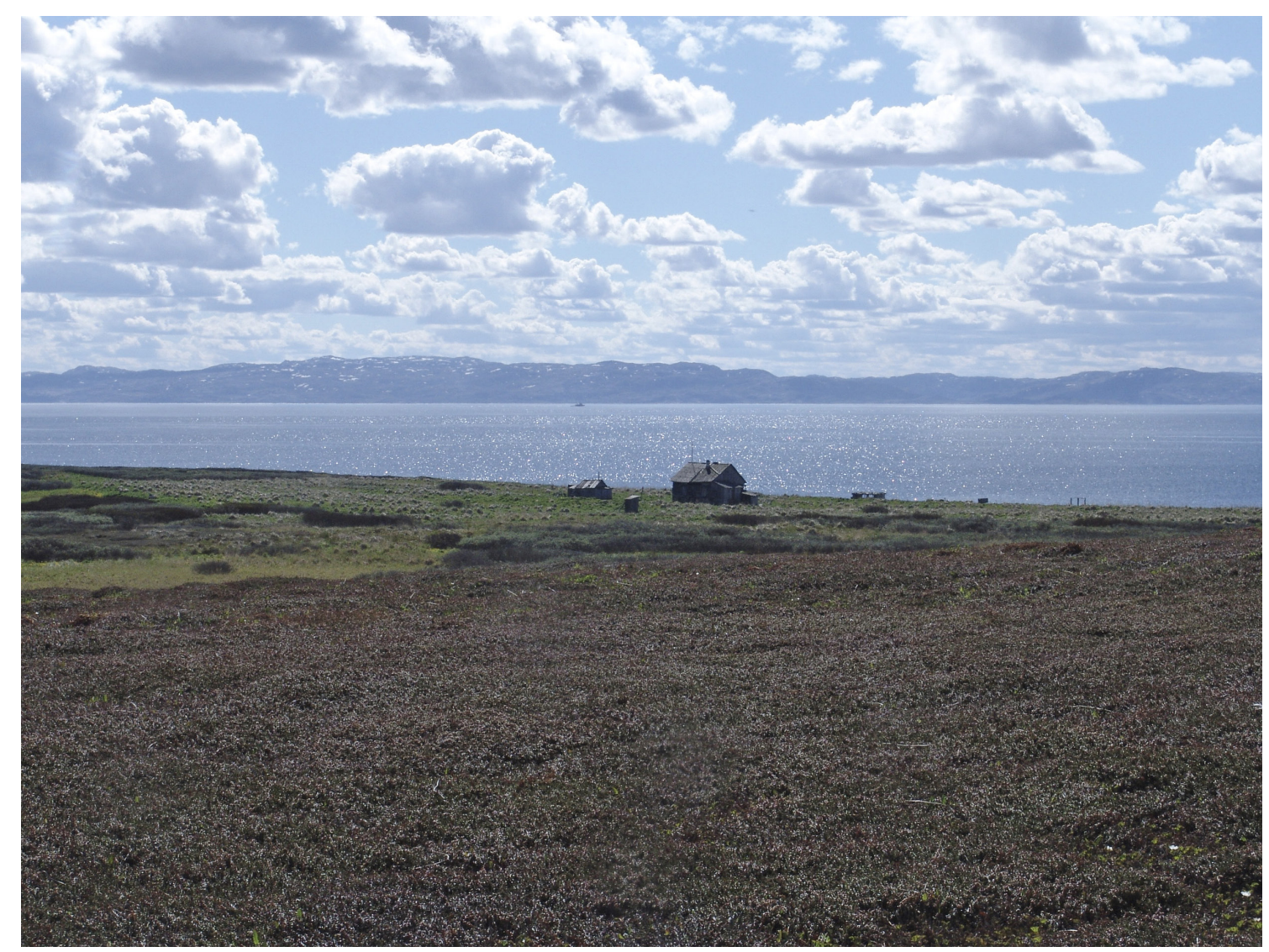

Figure 1. Landscape of the Greater Ainu Island.

The morphological terms are according to Sæther (1980). Larvae were identified using the following keys: Pankratova 1970, 1977, 1983 and Epler et al. 2013.

\section{Results}

Seven sampled sites yielded 15 species of Chironomidae larvae, belonging to three subfamilies (Table 2). Among them two species of Tanypodinae, nine species of Chironominae and four species of Orthocladiinae.

Highest species richness of eleven species was recorded for Lake Severnoe, while other lakes have richness of one-five species. Species of the subfamily Orthocladiinae were only recorded on the near-shore site of Lake Severnoe. Highest specimen density was recorded on the second site of Lake Severnoe, with the water depth 1.2 meters. This site was characterized by high numbers of Glyptotendipes paripes and Procladius sp.

\section{Discussion}

Among all the lakes sampled, Lake Severnoe was remarkably different in terms of chironomid species richness and diversity. This difference was probably caused by the proximity of a colony of marine birds, mainly puffin (Fratercula arctica (Linnaeus, 1758)) and cormorant (Phalacrocorax carbo (Linnaeus, 1758)). Nutrients from the faeces deposited in this colony are often washed away by the rains into the nearby Severnoe lake. In this lake a number of the species are traditionally associated with high nutrient load (Procladius sp., Chironomus sp.); there were also numerous phytophagous species (Cricotopus sp., Glyptotendipes paripes (Edwards, 1929), Psectrocladius obvius (Walker, 1856)) (Epler et al. 2013). We hypothesize that the higher species richness and specimen numbers of the Chironomidae larvae in Lake Severnoe were promoted by increased organic enrichment leached from bird faeces. The other lakes were further away from bird colonies, resulting in a lower influx of ornithogenic nutrients. Further research into the matter is required in order to assess the impact of the organic matter transfer by birds from the sea into the freshwater ecosystems. 
Table 2. List of chironomid larvae collected (by sites).

\begin{tabular}{|c|c|c|c|c|c|c|c|}
\hline Lake name & 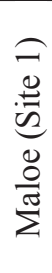 & 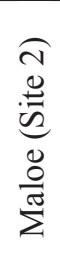 & 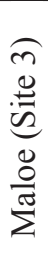 & 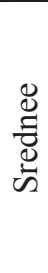 & 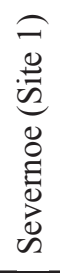 & 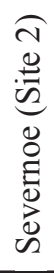 & 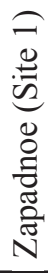 \\
\hline \multicolumn{8}{|l|}{ Subfamily Tanypodinae } \\
\hline Krenopelopia sp. & 1 & 2 & 2 & & & & \\
\hline Procladius sp. & & & & & & 49 & \\
\hline \multicolumn{8}{|l|}{ Subfamily Chironominae } \\
\hline Paratanytarsus sp. & & 1 & 2 & & 5 & 5 & \\
\hline Cladotanytarsus gr. vanderwulpi & & & & 1 & 1 & & \\
\hline Tanytarsus cf. usmaensis & & 1 & & & & & \\
\hline Tanytarsus cf. verralli & & & & & & 14 & \\
\hline Chironomus sp. & 4 & 1 & 1 & & 16 & & 1 \\
\hline Endochironomus dispar gr. & 1 & & 3 & 6 & 12 & 8 & \\
\hline Polypedilum (Ursipedilum) sp. & 1 & & & & & & \\
\hline Polypedilum gr. convictum & & & & 1 & & & \\
\hline Glyptotendipes paripes (Edwards, 1929) & & & & & & 73 & \\
\hline \multicolumn{8}{|l|}{ Subfamily Orthocladinae } \\
\hline Acricotopus sp. & & & & & 2 & & \\
\hline Cricotopus sp. & & & & & 8 & & \\
\hline Eukiefferiella sp. & & & & & 1 & & \\
\hline Psectrocladius obvius (Walker, 1856) & & & & & 2 & & \\
\hline
\end{tabular}

\section{Acknowledgments}

The authors are grateful to Henk Moller Pillot (Tilburg) for his assistance in checking the larval identifications as well as to Alexander Frolov (Murmansk Marine Biological Institute, RAS) for his participation in the initial processing of the samples, and to the administration of the Kandalaksha State Biosphere Reserve for the opportunity to work on Bolshoy Aynov island included in the area of the reserve.

\section{References}

Ellis, J.C., Farina, J. M. and Witman, J.D. 2006. Nutrient transfer from sea to land: The case of gulls and cormorants in the Gulf of Maine. - Journal of Animal Ecology 75: 565-574.

Epler, J.H., Ekrem, T. and Cranston, P.S. 2013. The larvae of Chironominae (Diptera: Chironomidae) of the Holarctic Region-Keys and Diagnosis. - Insect Systematics and Evolution, Supplement 66: 387-556.

Khleboslov, E.I., Khlebosolova, O.A., Chemjakin, R.G. and Tatarinkova, I.P. 2005. Nesting of the little gull on the Ainu isles of the Barents sea [In Russian]. - Russian Ornithological Journal 14: 831-832.

Pankratova, V.J. 1970. Lichinki i kukolki komarov podsemeistva Orthocladiinae fauny SSSR (Diptera, Chironomidae $=$ Tendipedidae) $[$ Larvae and pupae of midges of the subfamily Orthocladiinae (Diptera, Chironomidae $=$ Tendipedidae) of the USSR fauna]. - Opredeliteli po faune SSSR, izdavaemye Zoologicheskim Institutom AN SSSR 102, 1-344. Nauka. Leningrad. [In Russian].

Pankratova, V.J. 1977. Lichinki i kukolki komarov podsemeistva Podonominae i Tanypodinae fauny SSSR (Diptera, Chironomidae $=$ Tendipedidae) $[$ Larvae and pupae of midges of the subfamily Podonominae and Tanypodinae (Diptera, Chironomidae = Tendipedidae) of the USSR fauna]. - Opredeliteli po faune SSSR, izdavaemye Zoologicheskim Institutom AN SSSR 112: 1-154. Nauka. Leningrad. [In Russian].

Pankratova, V.J. 1983. Lichinki i kukolki komarov podsemeistva Chironominae fauny SSSR (Diptera, Chironomidae $=$ Tendipedidae $)[$ Larvae and pupae of midges of the subfamily Chironominae (Diptera, 
Chironomidae = Tendipedidae) of the USSR fauna]. - Opredeliteli po faune SSSR, izdavaemye Zoologicheskim Institutom AN SSSR 134: 1-296. Nauka. Leningrad. [In Russian].

Sæther, O.A. 1980. Glossary of chironomid morphology terminology (Diptera: Chironomidae). - Entomologica scandinavica, supplement 14: 1-51.

Tatur, A. 2002. Ornithogenic Ecosystems in the Maritime Antarctic - Formation, Development and Disintegration. In Bölter, M., Beyer, L. and Stonehouse, B. (Ed.), Ecological Studies: Geoecology of Antarctic Ice-Free Coastal Landscapes. Springer-Verlag, Berlin, pp. 161-184.

Article submitted 1. May 2017, accepted by Peter H. Langton 5. June 2017, published 7. June 2017. 